\title{
Identification of Gastrointestinal Protozoa in Long- Tailed Macaque (Macaca fascicularis) in Sabang
}

\author{
Farida Athaillah ${ }^{1}$, Alfi Wiratama Elpasha Ginting ${ }^{2}$, Erdiansyah Rahmi $^{3}$, Muhammad \\ Hambal $^{1}$, Muhammad Hasan ${ }^{4}$, Erwin Erwin ${ }^{4}$, Henni Vanda ${ }^{5}$ \\ ${ }^{1}$ Laboratory of Parasitology, Faculty of Veterinary Medicine, Universitas Syiah Kuala, Banda Aceh, Indonesia. \\ ${ }^{2}$ Veterinary Study Program, Faculty of Veterinary Medicine, Universitas Syiah Kuala, Banda Aceh, Indonesia. \\ ${ }^{3}$ Laboratory of Microbiology, Faculty of Veterinary Medicine, Universitas Syiah Kuala, Banda Aceh, Indonesia. \\ ${ }^{4}$ Laboratory of Clinical, Faculty of Veterinary Medicine, Universitas Syiah Kuala, Banda Aceh, Indonesia. \\ ${ }^{5}$ Laboratory of Pharmacology, Faculty of Veterinary Medicine, Universitas Syiah Kuala, Banda Aceh, Indonesia. \\ *Corresponding author. Email: Farida_athaillah@yahoo.com
}

\begin{abstract}
This study aimed to determine the types of gastrointestinal protozoa that infested long-tailed macaque (Macaca fascicularis) in Sabang Municipality. This study could be used as a basis of consideration for controlling zoonotic diseases caused by gastrointestinal protozoa. This research was conducted at the Laboratory of Parasitology, Faculty of Veterinary Medicine, Universitas Syiah Kuala. This study used 60 samples of M. fascicularis faeces collected from two sub-districts, 30 samples of Sukakarya District and 30 samples from Sukajaya District. Samples were examined using the floatation, formol ether, and modified acid-fast ziehl-neelsen method. The results showed that the highest infestation of protozoa in long-tailed macaque from Sukakarya was Cyclospora cayetanensis species (73\%), followed by the genus Eimeria sp. (53\%), Balantidium sp. (46\%) and Cryptosporidium parvum species (43\%). Long-tailed macaque from Sukajaya was found to be highly infested by Balantidium (53\%), followed by Eimeria sp. (46\%), Cyclospora cayetanensis (30\%) and Cryptosporidium parvum (13\%). The results exhibited that there were 4 genera or species of gastrointestinal protozoa that attack long-tailed macaque in Sabang City, namely Eimeria sp., Balantidium sp., Cyclospora cayetanensis and Cryptosporidium parvum species.
\end{abstract}

Keywords: Gastrointestinal protozoa, Cryptosporidium parvum, Macaca fascicularis, Sabang, Cyclospora cayetanensis

\section{INTRODUCTION}

Sabang island is located in the north of Sumatra Island and is part of Aceh Province. Sabang has great potential in developing as one of world destinations of tourism. This is due to the natural beauty that can spoil tourists who come to this city [1]. Not only for its natural beauty, Sabang City is also known as habitat for long-tailed macaque (Macaca fascicularis), and it becomes one of the main attractions in tourist areas. The long-tailed macaque is a primate that has a very close relationship with humans. The population of long-tailed macaque is spreaded across regions of Indonesia [2]. These primates are often used as pets and as experimental animals. Long-tailed macaques often interact directly with humans, and as a result they have potential to transmit zoonotic diseases to humans [3].
Parasitic disease, caused by worms or protozoa, can attack humans or animals, including primate species. Parasitic disease in primates plays an essential role in the primate group's population, both in-situ and ex-situ [4]. Protozoa are unicellular organisms that can only be seen microscopically. Gastrointestinal protozoan infestation occurred by ingesting of food or drink that has been contaminated by oocysts or by direct transmission. Gastrointestinal protozoa can cause several symptoms, such as abdominal discomfort, diarrhea, vomiting, and fever [5].

The most common gastrointestinal protozoa in primates are Balantidium sp, Eimeria sp, Entamoeba sp, Enteromonas sp, Blastocystis sp, Giardia sp, and Pseudolimax sp and Trichomonas sp [6]. Irene et al. [7] have conducted research on the Sumatran orangutan (Pongo abelii) and several protozoa were found including 
Entamoeba sp, Entamoeba histolyca, Blastocystis hominis, Enteromonas hominis, and Balantidium coli. Rahmi et al. [4] have conducted research on gastrointestinal parasites in long-tailed monkeys (Macaca fascicularis) in Weh island, Sabang Nature Park, and found that from 25 fecal samples, $12 \%$ were positive with Eimeria. sp. In this study, we would like to identify the types of gastrointestinal protozoa infested long-tailed monkeys, and this results could provide information about protozoal infection occurred in long-tailed monkeys in Sabang.

\section{MATERIALS AND METHODS}

This research was conducted at the Laboratory of Parasitology, Faculty of Veterinary Medicine, Universitas Syiah Kuala, Banda Aceh. The research sample used was 60 fresh feces from M. fascicularis obtained from Sukakarya dan Sukajaya subdistricts, and then added with $10 \%$ formalin. This research was a descriptive study using qualitative methods, namely Floatation, Formol-ether, and Ziel-Neelshen method. These methods were intended to identify the types of gastrointestinal protozoa infecting $M$. fascicularis. The results obtained will be presented in tabular form and microscopic images.

\subsection{FloatationMethod}

In this method, three grams of faecal samples were put into the mortar, distilled water was added and then the samples were homogenized. The homogenized samples were then transferred into $3 / 4$ volume of a centrifuge tube, and centrifuged at $1500 \mathrm{rpm}$ for 5 minutes. The supernatant was then removed, and the sheater sugar solution was added until the volume is $3 / 4$ of the tube. The samples were re-centrifuged at $1500 \mathrm{rpm}$ for 5 minutes. The tube was then placed on the tube rack perpendicularly, sheater sugar solution was added by using a pipette until the surface becomes convex. The samples were then incubated for three minutes. Afterward, the cover glass was carefully attached to the convex liquid surface, and the samples were examined under a microscope with an objective magnification of 40x [8].

\subsection{Formol-Ether Sedimentation Examination}

This method used 0.5 grams faecal samples and was put into a beaker glass which contained $7 \mathrm{ml}$ of $10 \%$ formalin and then homogenized. The faecal sample was transferred into a centrifuge tube and $3 \mathrm{ml}$ of ether was added. The samples were then homogenized and centrifuged for 3-5 minutes at $1500 \mathrm{rpm}$. After centrifugation, the supernatants and debris were removed. The sediment was dissolved with $10 \%$ formaldehyde sufficiently. The samples were placed on a glass object and observed under a microscope [9].

\subsection{Modified Fast Acid Ziehl-Neelsen}

In this method, 2-3 drops of faeces were placed on object glass and flattened as thin as possible, as if making a blood smear, then dried. The samples were then fixed in methanol for 3 minutes. Carbol fuchsin was added evenly and dried for 15-20 minutes, then washed with running water. Afterward, acid alcohol was added, dried for 15-20 seconds, and re-washed with running water. Then, malachite green or methylene blue was added for 30-60 seconds and washed under running water. The samples were dried and observed under a microscope with a magnification of 40x or 100x [10].

\section{RESULTS AND DISCUSSION}

The results of 60 samples of $M$. fascicularis faeces in Sabang City (Sukakarya and Sukajaya Districts) showed that four genera or species of gastrointestinal protozoa infected the long-tailed macaque, namely Eimeria sp., Balantidium sp., Cyclospora cayetanensis and Cryptosporidium parvum (Table 1).

Table 1. The prevalence of protozoal infections in Macaca fascicularis in Sabang City

\begin{tabular}{|l|l|l|}
\hline Sample & Genera/ Species & Case \\
\hline \multirow{5}{*}{$\mathrm{n}=60$} & Eimeria sp. & $30(50 \%)$ \\
\cline { 2 - 3 } & Balantidium sp. & $30(50 \%)$ \\
\cline { 2 - 3 } & Cyclospora cayetanensis & $31(51.67 \%)$ \\
\cline { 2 - 3 } & Cryptosporidium parvum & $17(28.33 \%)$ \\
\hline
\end{tabular}

From Table 1, it was shown that the prevalence rate of gastrointestinal protozoa from the four genera or species that infected long-tailed macaque in Sabang City was high. The highest prevalence was from Cyclospora cayetanensis (51.67\%), followed by Eimeria sp. (50\%), Balantidium sp. (50\%) and Cryptosporidium parvum $(28.33 \%)$. The high prevalence of protozoa infestation could be because of these primates live in the wild and never been given anti-protozoal drugs. Also probably due to low awareness and regulations by local authorities and local communities. Lack of food source could also resulted in having a poorly nutritious diet [11]. Most of long-tailed macaque in Sabang Municipality forage by going to the streets and sometimes even to residential areas, causing high opportunity of being trasmitted infectious diseases, including gastrointestinal protozoal infections. Observations in the field showed that several long-tailed macaques in Sabang Municipality had unique behavior, for instance, picking out another individual's anus and then putting his hand in his mouth. This behavior could be one of the factors in the high prevalence of protozoal infestation in long-tailed macaque in Sabang 
Municipality. The prevalence of protozoal infestation in each subdistrict is provided in Table 2 and Table 3 .

Table 2. The prevalence of protozoal infections in Macaca fascicularis faeces in Sukakarya Subdistrict.

\begin{tabular}{|l|l|l|}
\hline Sample & Genera/Species & Case \\
\hline \multirow{5}{*}{$\mathrm{n}=30$} & Eimeria sp. & $16(53 \%)$ \\
\cline { 2 - 3 } & Balantidium sp. & $14(46 \%)$ \\
\cline { 2 - 3 } & Cyclospora cayetanensis & $22(73 \%)$ \\
\cline { 2 - 3 } & Cryptosporidium parvum & $13(43 \%)$ \\
\hline
\end{tabular}

Table 3. The prevalence of protozoal infections in Macaca fascicularis feces in Sukajaya Subdistrict.

\begin{tabular}{|l|l|l|}
\hline Sample & Genera/Species & Case \\
\hline \multirow{3}{*}{$\mathrm{n}=30$} & Eimeria sp. & $14(46 \%)$ \\
\cline { 2 - 3 } & Balantidium sp. & $16(53 \%)$ \\
\cline { 2 - 3 } & Cyclospora cayetanensis & $9(30 \%)$ \\
\cline { 2 - 3 } & Cryptosporidium parvum & $4(23 \%)$ \\
\hline
\end{tabular}

Based on Table 2, the prevalence of protozoa infested 30 samples of long-tailed macaque in Sukakarya subdistrict was from Cyclospora cayetanensis species (73\%), followed by the genus Eimeria sp. (53\%), Balantidium sp. (46\%) and Cryptosporidium parvum (43\%). Table 3 showed that 30 samples of long-tailed macaque faeces in Sukajaya subdistrict were highly infested by Balantidium sp. (53\%), followed by Eimeria sp. (46\%), Cyclospora cayetanensis (30\%) and Cryptosporidium parvum (13\%). The forest geographic condition in Sukakarya and Sukajaya subdistricts is quite similar so the protozoa found in long-tailed macaque in these two districts were also similar.

The results of this study are in line with the results of a research conducted by Ekanayake et al. [12]. This group reported that protozoal infections in wild primates in Polonnaruwa, Sri Lanka were caused by Balantidium coli, Entamoeba coli, Chilomastix spp. Entamoeba histolyca, Entamoeba hartmanni, and Cryptosporidium sp. This result is also aligned with Rahmi et al. [4] where this group found $12 \%$ of Eimeria sp. oocysts in macaque in Pulau Weh Nature Park.

The highest prevalence of protozoal infections in macaque in Sukakarya subdistrict was caused by Cyclospora cayetanensis (73\%), this could be due to oocysts of Cyclospora sp. needs 7-15 days to sporulate with an optimum temperature of $5-25^{\circ} \mathrm{C}$ [13]. The forest atmosphere in Sabang City is humid and supported the survival cycle of Cyclospora sp. Moreover, this could cause a large amount of Cyclospora sp. in the digestive tract of $M$. fascicularis. In addition, the water contaminated with faeces of $M$. fascicularis can also potentially transmit the disease to other macaques. The long-tailed macaques in Sukakarya District, precisely at Kilometer Zero, are usually consume their food close to the streets, and also expectfoods from tourists. Many of these primates scavenged for leftover foods from tourists in the trash cans, which can also be a factor in the high prevalence of Cyclospora sp. infection. Wirawan et al. [14] reported that cross-infection between individuals could occur due to interactions when consuming water and food together in one area.

The highest prevalence rate of protozoa infecting longtailed macaques in Sukajaya subdistrict was Balantidium sp. (53\%) (Table 3). Selian et al. [15] stated that Balantidium coli are commonly found in primates. The amount of Balantidium sp. infestation could be due to transmission from other infected macaque, a polluted environment, and also contaminated water. The longtailed macaques in Sukakarya and Sukajaya Districts have been infected bythe same types of protozoa, the only difference is the level of infection caused by each type. The prevalence rate of Balantidium sp. infestation in these two subdistricts was similar, which could be attributed to the present of boars in the forest of these districts that could potentially transmit balantidiosis to long-tailed macaque or vice versa. Agustina et al. [16] has carried out research related to protozoa in the digestive tract of pigs, and the results indicated that Balantidium sp. was found in $61.2 \%$ ofpigs sold in traditional markets in Bali.

The prevalence rate of Eimeria sp. also showed no difference between two districts, probably due to similar geographic condition of the forest which allows the spread of these protozoa in both subdistricts.

Cyclospora cayetanensis and Cryptosporidium parvum infections indicated that these protozoa were found mostly in long-tailed macaque (in Sukakarya subdistrict compared to Sukajaya subdistrict. This condition might be caused by the contaminated environment with oocysts.

Sukakarya subdistrict has more visitors than Sukajaya subdistrict, and tourists often spoiled the macaque by feeding them. This habit could cause oocystic contamination in food, soil and drinking water which resulted in infection among macaque group in Sukakarya District. Oocysts of protozoa found in long-tailed macaque faeces examination in two sub-districts in Sabang Municipality can be seen in Figure 1 below. 


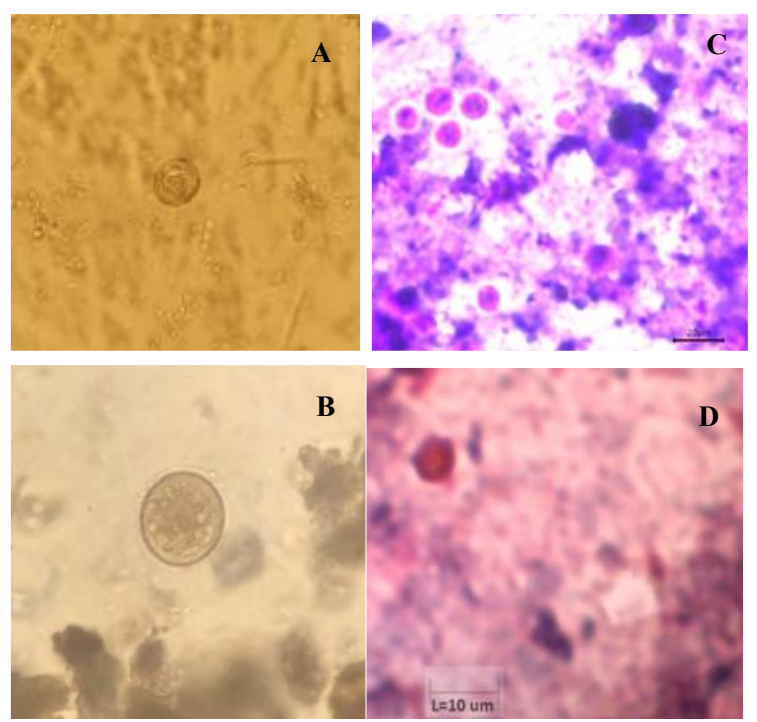

Figure 1. Examination of long-tailed monkey faeces (A). Oocyst Eimeria sp. (40x) (B). Balantidium sp. Cysts (40x) (C). Cyclospora cayetanensis oocyst (100x) (D). Cryptosporidium parvum oocyst (100x)

Azmy et al. [17] conducted a study of 100 soil samples examined around the landfill in Denpasar and found that 5\% of the soil studied contained oocysts from the Coccidia family. He described that the tropical environment was the optimum environment for protozoan development. Longtailed macaque live in groups where one group consists of males and females [18]. Maclntosh et al. [19] stated that animals living in the same population have a high likelihood of disease transmission among these animals.

Symptoms caused by infection of Eimeria sp. oocysts were diarrhea, bloody faeces and the presence of mucus. The stool could be red to black and died epithelial cell could be seen microscopically [20]. Although the faeces of long-tailed monkeys did not show any symptoms such as blood, the results showed oocysts of Eimeria sp. sp. was highly presented in stool samples.

Protozoal infections of other genera such as Balantidium sp. (Figure B) could be identifies by the presence of cysts in long-tailed macaquefaeces samples in two sub-districts in Sabang Municipality. In the research of Selian et al. [15], 40\% of protozoa such as Balantidium coli were found in the faeces of the Sumatran orangutan (Pongo abelii) in the Jantho Pine Nature Reserve, Aceh Besar District.

The transmission of protozoal infestations in this study occured through contaminated food withoocysts in the soil. Research conducted by Lestari and Mulyowati [21] found two trophozoid Balantidium coli with oval and gray-green characteristics on the body of the Chrysomya megachepala fly which was collected at the Surakarta Legi Market.

Cyclospora cayetanensis oocysts (Figure C) were also found in long-tailed macaque faeces in Sabang Municipality.
Cyclospora cayetanensis oocysts are $8-10 \mu \mathrm{m}$ in size and round in shape, have very thin walls $(<1 \mu \mathrm{m})$ and are colorless [22]. The diameter of the Cyclospora oocysts that can be obtained through the stool examination reaches an average of $8-10 \mu \mathrm{m}$ which indicates that these oocysts are oocysts of Cyclospora cayetanensis. The transmission of Cyclospora cayetanensis could be through contamination of food, water, and soil with oocysts from Cyclospora cayetenensis. Wahdini et al. [23] examined student stool samples where two people were positive for Cyclospora sp. This could be attributed to poor hygiene of the students in washing the fruit. Cyclospora cayetanensis in the digestive tract destroyed epithelial cells in the duodenum and jejenum [22]

The results of this study also indicated that long-tailed macaque have been infected by Cryptosporidium parvum oocysts (Figure D) in each sub-district in Sabang Municipality. Protozoa of the genus Cryptosporidium are often found in wild primates and can potentially transmitted to humans or livestock [24]. Long-tailed macaque stool samples showed a consistency of liquid (predominantly containing water) and mushy (solid-like but not hard) which indicates that the monkey had diarrhea. According to Wijayanti [25], Cryptosporidiasis are a zoonotic disease caused by Cryptosporidium where the parasite infects the small intestine causing acute diarrhea. Transmission occurs through intermediate hosts such as rats or environments that have been contaminated with oocysts such as soil and water.

The oocysts of the genus Cryptosproridium are 3-8 $\mu \mathrm{m}$ in diameter, round or oval in shape. Cryptosporidium parvum oocysts have an oval shape, are round and range in diameter (4.6 - $5.4 \times 3.8-4.7 \mu \mathrm{m}$ ) [26]. The average size of the oocysts obtained in this study was $(4-8 \mu \mathrm{m})$ in diameter. Oocysts from Cryptosporidium have been widely distributed in Indonesian waters, such as in the sea, ponds or rivers. Oocysts can survive in humid environmental conditions, cold environments, and can even survive in chlorinated water [25, 27]. Given that the geographical conditions of Sabang City are surrounded by oceans, there is a possibility for Cryptosporidium oocyst contaminates the waters in Sabang City and could be a potential transmission to the community, both local people and tourists. Maryanti et al. [28] described that Cryptosporidium infection in humans usually occurs in humans under five years of age. Wijayanti [25] also stated that the prevalence of diarrhea caused by Cryptosporidium in infants and children has reached $5-15 \%$, but it does not rule out that adults could also be infected.

\section{CONCLUSION}

Based on the results of the research conducted, four types of protozoa was infected long-tailed macaque, namely Eimeria sp., Balantidium sp., Cyclospora cayetanensis and Cryptosporidium parvum in two sub-districts in Sabang Municipality. In Sukakarya subdistrict, the highest infestation of protozoa was caused by Cyclospora cayetanensis with $73 \%$ prevalance rate, while in Sukajaya 
subdistrict the highest infestation was Balantidium sp. with $53 \%$ prevalence rate.

\section{AUTHORS' CONTRIBUTIONS}

All authors equally contributed to the preparation and editing of the manuscript.

\section{ACKNOWLEDGMENT}

The authors thank the Faculty of Veterinary Medicine, Universitas Syiah Kuala.

\section{REFERENCES}

[1] Zalikha, Peluang dan tantangan pelaksanaan wisata di Kota Sabang. Jurnal Al-Bayan 22(31) (2015) 90107.

[2] R. Triani, T. Haryono, U. Faizah, Identifikasi telur endoparasit saluran pencernaan Macaca fascicularis yang dipergunakan pada pertunjukan topeng monyet di Surabaya melalui pemeriksaan feses. LenteraBio, 3 (2014) 3 .

[3] I.G. Soma, I.N., Wandia, I.G.A.A. Putra, L. Silta, Profil darah monyet ekor panjang (Macaca fascicularis) liar di habitat alami. Ilmu dan Kesehatan Hewan, 1 (2013) 22-28.

[4] E. Rahmi, M. Hanafiah, A. Sutriana, M. Hambal, F. Wajidi, Insidensi nematoda gastrointestinal dan protozoa pada monyet ekor panjang (Macaca fascicularis) liar di Taman Wisata Alam (TWA) Pulau Weh Sabang. Ilmu-Ilmu Peternakan, 13(6) (2010) 289-291.

[5] M. Marzain, E. Novita, E. Semiarty, Identifikasi protozoa usus pada pasien yang sedang menjalani kemoterapi di RSUP Dr M Djamil, Padang. Jurnal Kesehatan Andalas, 7(3) (2018) 364-369.

[6] R. Lacoste, Intestinal parasites of the crab - eating macaques (Macaca fascicularis): Experimental study and recommendations for the diagnosis and the management of rhizoflagellates and ciliates. Thesis. National Alfort Veterinary School, 2009.

[7] F.M. Irene, W. Paembonan, I. Singleton, S.A. Wich, G. Hester, V. Bolhous, Intestinal parasites of freeranging, semicaptive, and captive Pongo abelii in Sumatra, Indonesia. Int J Primatol. 28 (2007) 407420.

[8] I.G.J.R. Glantiga, I.B.M. Oka, I.K. Puja, Prevalensi infeksi protozoa saluran pencernaan pada anjing kintamani Bali di Desa Sukawan, Kecamatan Kintamani, Kabupaten Bangli, Bali. Indonesia Med.Vet. 5(5) (2016) 446-453.

[9] E. Susanty, Teknik konsentrasi formol eter untuk mendiagnosa parasit usus. Jurnal Kesehatan Melayu 1(2) (2018) 125-129.
[10] D.P. Casemore, M. Amstrong, R.L. Sands, Laboratory diagnosis of cryptosporidiosis. J. Clin Pathol 38(12) (1985) 1337-1341.

[11] F. Perveen, Karimullah, S. Anuar, Long-tailed macaques, Macaca fascicularis (Primate: Cercopithecidae): human-monkey behavioural interaction in Botanical Garden Penang, Malaysia. Ann. Exp. Bio, 2(1) (2014) 36-44.

[12] D.K. Ekanayake, A. Arulkanthan, N.U. Horadagoda, G.K.M. Sanjeevani, R. Kieft, S. Gunatilake, W.P.J. Dittus, Prevalence of Cryptosporidium and other enteric parasites among wild non-human primates in Polonnaruwa, Sri Lanka. Amj. Top. Med. Hyg, 74(2) (2006) 322-329.

[13] Y.R. Ortega, L.J. Robertson, Cyclospora cayetanensis as a Foodborne Pathogen. Springer International Publisher AG, Switzerland, 2017.

[14] Wirawan, I.G.K.O., Kusumaningrum, D dan Oematan, A.B. (2015). Keragaman endoparasit gastrointestinal pada Macaca fascicularis di Taman Wisata Goa Monyet Tenau Kota, Kupang. Sain Veteriner. 33(1): 92-104.

[15] R.M. Selian, M. Hanafiah, E. Rahmi, Identifikasi parasite gastrointestinal pada feses monyet orangutan sumatera (Pongo Abelii) semi liar di kawasan cagar alam pinus Jantho Kabupaten Aceh Besar. Jesbio 2(1) (2013) 26-31.

[16] K.K. Agustina, N.M.A.A. Sudewi, A.A.G.O Dharmayudha, I.B.M. Oka, Identifikasi dan prevalensi infeksi protozoa saluran cerna anak babi yang dijual di pasar tradisional di wilayah Provinsi Bali. Buletin Veteiner Udayana 8(1) (2016) 17-24.

[17] A.A. Azmy, I.A.P. Apsari, I.B.K. Ardana, Isolasi dan identifikasi ookista koksidia dari tanah di sekitar tempat pembuangan sampah di Kota Denpasar. Indonesia Med. Vet., 4(2) (2015) 163-169.

[18] I. Hakiki, J. Sutriani, S. Susanti, Prilaku memilih lokasi bermalam monyet ekor panjang (Macaca fascicularis) di perkebunan pala Desa Sawang Ba'u Kecamatan Sawang kabupaten Aceh Selatan. Prosiding Seminar Nasional Biotik. 2(1) (2015) pp. 53-57.

[19] A.J.J. Maclntosh, A. Jacobs, C. Garcia, K. Shimizu, K. Mouri, M.A. Huffman, A.D. Hernandez, Monkeys in the middle: parasite transmission through the social network of a wild primate. Plos One 7(12) (2012).

[20] Z. Doviansyah, Prevalensi koksidiosis dan identifikasi ookista Eimeria spp. pada sapi perah di Kawasan Usaha Ternak (KUNAK) Kabupaten Bogor. Skripsi, IPB, Bogor, 2015.

[21] H.D. Lestari, T. Mulyowati, Identifikasi Entamoeba hystolitica dan Balantidium coli pada lalat di Pasar Surakarta. Jurnal Biomedia 12(1) (2019) 79-83. 
[22] S. Almeria, H.N. Cinar, J.P. Dubey, Cyclospora cayetanensis and Cyclosporiasis. Agricult. Res. (2019)

[23] S. Wahdini, P. Sudarmono, A.W. Wardhana, F.P. Irmawati, R.A. Haswinzky, Y.A. Dwinastiti, S. Sungkar, Penyakit parasitic pada anak sekolah berasrama di Kabupaten Bogor. eJKI 6(3) (2018) 207-211.

[24] J.S. Salzer, I.B. Rwego, T.L. Goldberg, Kuhlenschmidt, T.R. Gillespie, Giardia sp. and Cryptosporidium sp. infection in primates in fragmented and undisturbed forest in Western Uganda. J. Parasitol. 93(2) (2007) 439-440.

[25] T. Wijayanti, Kriptosporidiasis di Indonesia. Balaba 13(1) (2017) 73-82.

[26] M.A. Taylor, R.L. Coop, R.L. Wall, Veterinary Parasitology. Library of Congress Cataloging, British, 2016.

[27] E. Maryanti, Epidemiologi kriptosporidiosis. JIK 5(1) (2011) 1-6.

[28] E. Maryanti, H. Rahmi, S.D. Lesmana, L. Haslinda, Deteksi Cryptosporidium sp. dengan pewarnaan modifikasi tahan asam pada tinja sisw SDN X Kecamatan Rumbai, Pekanbaru. JIK 8(1) (2014) 25 28. 